\title{
Interaction between Ephrins and mGlu5 Metabotropic Glutamate Receptors in the Induction of Long-Term Synaptic Depression in the Hippocampus
}

\author{
Sonia Piccinin, ${ }^{1}$ Carlo Cinque, ${ }^{1}$ Laura Calò, ${ }^{1}$ Gemma Molinaro, ${ }^{2}$ Giuseppe Battaglia, ${ }^{2}$ Laura Maggi, ${ }^{1}$ \\ Ferdinando Nicoletti, ${ }^{1,2}$ Daniela Melchiorri, ${ }^{1,3}$ Fabrizio Eusebi, ${ }^{1,2}{ }^{\dagger}$ Peter V. Massey, ${ }^{4}$ and Zafar I. Bashir ${ }^{4}$ \\ ${ }^{1}$ Department of Physiology and Pharmacology, University “Sapienza," 00185 Rome, Italy, ${ }^{2}$ Istituto Neurologico Mediterraneo Neuromed, 86077 Pozzilli, \\ Italy, ${ }^{3}$ Instituto di Ricovero e Cura a Carattere Scientifico San Raffaele Pisana, 00163 Roma, Italy, and ${ }^{4}$ Medical Research Council Centre for Synaptic \\ Plasticity, Department of Anatomy, University of Bristol, Bristol BS8 1TD, United Kingdom
}

We applied the group-I metabotropic glutamate (mGlu) receptor agonist, 3,5-dihydroxyphenylglycine (DHPG), to neonatal or adult rat hippocampal slices at concentrations $(10 \mu \mathrm{M})$ that induced a short-term depression (STD) of excitatory synaptic transmission at the Schaffer collateral/CA1 synapses. DHPG-induced STD was entirely mediated by the activation of mGlu5 receptors because it was abrogated by the mGlu5 receptor antagonist, MPEP [2-methyl-6-(phenylethynyl)pyridine], but not by the mGlu1 receptor antagonist, CPCCOEt [7-(hydroxyimino)cyclopropa[b]chromen-1a-carboxylate ethyl ester]. Knowing that ephrin-Bs functionally interact with group-I mGlu receptors (Calò et al., 2005), we examined whether pharmacological activation of ephrin-Bs could affect DHPG-induced STD. We activated ephrin-Bs using their cognate receptor, EphB1, under the form of a preclustered EphB1/Fc chimera. Addition of clustered EphB1/Fc alone to the slices induced a small but nondecremental depression of excitatory synaptic transmission, which differed from the depression induced by $10 \mu \mathrm{M}$ DHPG. Surprisingly, EphB1/Fc-induced synaptic depression was abolished by MPEP (but not by $\mathrm{CPCCOEt}$ ) suggesting that it required the endogenous activation of mGlu5 receptors. In addition, coapplication of DHPG and EphB1/Fc, resulted in a large and nondecremental long-term depression. The effect of clustered EphB1/Fc was specific because it was not mimicked by unclustered EphB1/Fc or clustered EphA1/Fc. These findings raise the intriguing possibility that changes in synaptic efficacy mediated by mGlu5 receptors are under the control of the ephrin/Eph receptor system, and that the neuronal actions of ephrins can be targeted by drugs that attenuate mGlu5 receptor signaling.

\section{Introduction}

Ephrins and "Eph" receptors are membrane-anchored proteins that regulate tissue patterning, cell migration, and axonal targeting during CNS development (Flanagan and Vanderhaegen, 1998; Dalva et al., 2000; Wilkinson, 2001; Kullander and Klein, 2002). The Eph receptor family includes nine EphA and five EphB receptor subtypes interacting with ephrin-A1-5 and ephrin-B1-3, respectively. Interaction requires cell-cell contacts and the formation of tetrameric complexes in which each ligand interacts with two receptors and vice versa (Himanen et al., 2004). Activated ephrins and Eph receptors generate bidirectional signals, which are mediated by the tyrosine kinase activity of Eph receptors on one side, and by the recruitment of soluble tyrosine kinases and other effectors on the other side (Holland et al., 1996; Brückner et al., 1997; Kullander and Klein, 2002).

\footnotetext{
Received Sept. 29, 2009; accepted Nov. 6, 2009.

This work was supported by the Wellcome Trust.

This work is dedicated to the memory of Prof. Fabrizio Eusebi.

†Deceased.

Correspondence should be addressed to Sonia Piccinin, Department of Physiology and Pharmacology, University

"Sapienza," Piazzale A. Moro 5, 00185 Rome, Italy. E-mail: sonia.piccinin@uniroma1.it.

DOI:10.1523/JNEUROSCI.4834-09.2010

Copyright $\odot 2010$ the authors $\quad 0270-6474 / 10 / 302835-09 \$ 15.00 / 0$
}

Ephrins/Eph receptors participate in the regulation of synaptic plasticity during development and in the adult life. This function involves an interaction between ephrins/Eph receptors and ionotropic glutamate receptors, particularly NMDA and AMPA receptors (Calò et al., 2006). Ephrins and Eph receptors associate with proteins that regulate AMPA receptor trafficking (Torres et al., 1998; Brückner et al., 1999; Lin et al., 1999; Irie et al., 2005). In addition, EphB1-4 receptors physically associate with NMDA receptors (Dalva et al., 2000) and positively regulate NMDA receptors in cultured neurons (Takasu et al., 2002). The role of ephrins/Eph receptors in activity-dependent forms of synaptic plasticity has been investigated in the hippocampus. At the Schaffer collateral/ CA1 pyramidal cell synapses, postsynaptic ephrin-Bs are required for the induction of NMDA-dependent long-term potentiation (LTP) (Grunwald et al., 2004; Rodenas-Ruano et al., 2006; see Armstrong et al., 2006 for contrasting results). Postsynaptic ephrin-B2/B3 are also required for the induction of long-term depression (LTD) at the CA3-CA1 synapses (Grunwald et al., 2004). In contrast, presynaptic ephrin-Bs are required for LTP induction at the mossy fiber-CA3 synapses (Contractor et al., 2002; Armstrong et al., 2006). We have recently found that ephrin-Bs interact with group-I metabotropic glutamate receptors (mGlu1 and mGlu5 receptors). Both mGlu1a and mGlu5 receptors coim- 
munoprecipitate with ephrin-B2, and activation of ephrin-Bs by a clustered EphB1 receptor/Fc chimera amplifies mGlu1 receptor signaling in striatal slices (Calò et al., 2005). Group-I mGlu receptors, particularly mGlu5 receptors, have an established role in the induction of LTP and LTD (Riedel et al., 1996; Anwyl, 1999; Bortolotto et al., 1999; Cho and Bashir, 2002; Naie and ManahanVaughan, 2004; Neyman and Manahan-Vaughan, 2008). This role has been highlighted in mouse models of fragile-X syndrome, where mGlu5-receptor-mediated LTD is amplified in the hippocampus (Huber et al., 2002; Bear et al., 2004; Dölen and Bear, 2008).

Here we examined whether the interaction between ephrin-Bs/ EphB receptors and group-I mGlu receptors is involved in the induction of synaptic depression in the hippocampus. We addressed this issue by monitoring the effect at the Schaffer collaterals-CA1 synapses of the selective group-I mGlu receptor agonist, 3,5,dihydroxyphenylglycine (DHPG) (Palmer et al., 1997; Fitzjohn et al., 1999; Huber et al., 2000, 2001) and the effect of activation of endogenous ephrin-Bs using a clustered EphB1 receptor/Fc chimera.

\section{Materials and Methods}

\section{Drugs}

3,5-Dihydroxyphenylglycine (DHPG), 7-(hydroxyimino)cyclopropa [b]chromen-1a-carboxylate ethyl ester (CPCOOEt), 2-methyl-6(phenylethynyl)pyridine (MPEP), and 1,4-diamino-2,3-dicyano-1,4-bis [2-amino-phenylthio] butadiene (UO126) were purchased from Tocris Bioscience. 2-(4-Morpholinyl)-8-phenyl-1(4H)-benzopyran-4-one hydrochloride (LY294002) was purchased from Sigma-Aldrich. A chimeric protein containing the extracellular domain of rat EphB1 receptor (amino acid residues 1-538) or of human EphA1 receptor (amino acid residues 1-547) fused to the $\mathrm{C}$-terminal $6 \times$ histidine-tagged $\mathrm{Fc}$ region of human IgG via a polypeptide linker (Sigma-Aldrich, R\&D Systems) was clustered by a $40 \mathrm{~min}$ incubation at $37^{\circ} \mathrm{C}$ with an AffiniPure goat antihuman IgG, $\mathrm{Fc}_{\gamma}$-specific $(111 \mathrm{ng} / \mathrm{ml})$.

\section{Electrophysiological studies}

Preparation of hippocampal slices. Neonate (7- to 9-d-old) or adult (4week-old) male Wistar rats (Charles River) were killed by an overdose of isoflurane followed by cervical dislocation. The brains were rapidly removed and mounted on a steel plate: $400 \mu \mathrm{m}$ thick sections of the whole brain were prepared using a vibroslicer (DSK, Dosaka EM). Sectioning was performed in cold $\left(\sim 4^{\circ} \mathrm{C}\right)$ artificial CSF (aCSF) containing the following (in mM): $124 \mathrm{NaCl}, 3 \mathrm{KCl}, 26 \mathrm{NaHCO}_{3}, 2 \mathrm{CaCl}_{2}, 1.25 \mathrm{NaH}_{2} \mathrm{PO}_{4}$, $1 \mathrm{MgSO}_{4}$, and 10 glucose. The aCSF was continuously bubbled with carbogen $\left(95 \% \mathrm{O}_{2}-5 \% \mathrm{CO}_{2}\right)$. After slicing, the hippocampus was dissected and transferred to a submerged chamber continuously perfused with carbogen-bubbled aCSF at room temperature.

Extracellular recordings and analysis. After an equilibration period of $\geq 1$ h extracellular field potentials were recorded from the stratum radiatum of the CA1 region using glass micropipettes (2-4 M $\Omega$ ) filled with aCSF. Electrical stimulation was delivered using a concentric bipolar stimulating electrode (Frederick Haer). Stimuli were produced by constant voltage isolated stimulator boxes (Digitimer) and comprised a square-wave pulse, $20-200 \mu$ s in duration and 1-20 V in amplitude. Signals were amplified X1000 using an AxoClamp-2-A amplifier (Molecular Devices) and then low-pass filtered at $2 \mathrm{kHz}$, digitized at $5 \mathrm{kHz}$, captured using Clampex 9.2 software (Molecular Devices), and stored on a PC hard disk for off-line analysis. The stimulation strength was adjusted to obtain $50 \%$ of the maximal synaptic response by monitoring the slope of field EPSPs (fEPSPs). In each experiment, measurements of each individual parameter were averaged over 5 consecutive min. These values were normalized relative to mean value obtained over the $20 \mathrm{~min}$ period before drug application. Paired-pulse facilitation (PPF) is the potentiation of the response to the second of a pair of stimuli and represents a form of presynaptic short-term plasticity. Changes in PPF can provide an indication of changes in transmitter release probability (Zucker, 1989).
When applied, paired stimuli (interstimulus interval of $50 \mathrm{~ms}$ ) consisted of $100 \mathrm{~ms}$ constant current square pulses, applied at $0.2 \mathrm{~Hz}$.

\section{Measurement of polyphosphoinositide (PI) hydrolysis in hippocampal slices}

Hippocampal slices $(350 \times 350 \mu \mathrm{m})$ were prepared from neonate rats, as described previously (Nicoletti et al., 1986), and incubated at $37^{\circ} \mathrm{C}$ under constant oxygenation for $45 \mathrm{~min}$ in Krebs-Henseleit buffer, $\mathrm{pH}$ 7.4. Forty microliters of gravity packed slices were transferred to vials containing 1 $\mu \mathrm{Ci}$ of $m y o-\left[2-{ }^{3} \mathrm{H}\right]$ inositol (specific activity, $10 \mathrm{Ci} / \mathrm{mmol}$; GE Healthcare, Milan, Italy) to label inositol phospholipids. At the end of this incubation, $10 \mathrm{~mm} \mathrm{LiCl}$ was added, followed $10 \mathrm{~min}$ later by the mGlu 1/5 receptor agonist, DHPG. When present, mGlu receptor antagonists and/or clustered EphB1/Fc were added 5-10 min before DHPG. The incubation was continued for $60 \mathrm{~min}$ and then terminated by the addition of methanol:chloroform:water (1:1:1). The amount of $\left[{ }^{3} \mathrm{H}\right]$ inositol monophosphate (InsP) accumulated during the reaction was measured by anion exchange chromatography as described previously (Nicoletti et al., 1986).

Assessment of the MAP kinase (MAPK) and the

phosphatidylinositol-3-kinase (PI-3-K) pathways in hippocampal slices

Neonate hippocampal slices prepared as above were preincubated in oxygenated Krebs/Henseleit buffer, $\mathrm{pH} 7.4$, for $3 \mathrm{~h}$ in an attempt to reduce the background activity of the MAPK and the PI-3-K pathways, and then challenged with DHPG and clustered EphB1/Fc alone or in combination for $10 \mathrm{~min}$. The incubation was terminated by washing the slices in ice-cold buffer. Slices were lysed in Triton X-100 lysis buffer [containing the following (in $\mathrm{mm}$ ): 50 Tris- $\mathrm{HCl}, \mathrm{pH} 7.5,1 \%$ Triton $\mathrm{X}-100,100 \mathrm{NaCl}, 5 \mathrm{EDTA}, 50 \mathrm{NaF}, 40 \beta$-glycerophosphate, 200 sodium ortovanadate, 100 PMSF, $1 \mu \mathrm{g} / \mathrm{ml}$ leupeptin, $1 \mu \mathrm{g} / \mathrm{ml}$ pepstatin A) for 15 $\min$ at $4^{\circ} \mathrm{C}$. Samples were centrifuged at $12,000 \times g$ for $10 \mathrm{~min}$ at $4^{\circ} \mathrm{C}$. Equal amounts of proteins $(100 \mu \mathrm{g})$ from supernatants were separated by $12.5 \%$ (p-ERK1/2) or $7.5 \%$ (p-Akt) SDS-polyacrylamide gel. After separation, proteins were transferred on nitrocellulose membranes. Membranes were incubated with an antibody against phosphorylated extracellular signal regulated kinase, ERK1/2 (phospho-p44/42 MAPK monoclonal antibody, 1:2000; New England Biolabs Inc.) for $2 \mathrm{~h}$ at room temperature or with an antibody against phosphorylated Akt (1:1000, rabbit polyclonal phospho-Akt (Ser473) antibody; New England Biolabs Inc.) overnight at $4^{\circ} \mathrm{C}$. Blots were then incubated for $1 \mathrm{~h}$ with the secondary antibody (1:5000, peroxidase-coupled anti-mouse or 1:8000, peroxidasecoupled anti-rabbit; GE Healthcare). Immunostaining was revealed by the enhanced ECL Western blotting analysis system (GE Healthcare). The same blots were normalized against anti-ERK1/2 or anti-Akt antibodies (1:1000; New England Biolabs Inc.).

\section{Western blot analysis of $m G l u 5$ receptors in ephrin-B2} and KCC2 immunoprecipitates

Western blot analysis of mGlu5 receptors in ephrin-B2 immunoprecipitates from the hippocampus of neonate rats was performed as described previously (Calò et al., 2005). In brief, $1 \mathrm{mg}$ of lysate was incubated with $5 \mu \mathrm{g}$ of rabbit polyclonal ephrin-B2 immunoprecipitating antibody (Santa Cruz Biotechnology) or rabbit polyclonal anti- $\mathrm{K}^{+} / \mathrm{Cl}^{-}$synporter (KCC2) antibodies (Millipore Biotechnology) and bound to protein A-Sepharose beads (Sigma-Aldrich). For Western blot analysis, proteins were resuspended in SDS-bromophenol blue buffer containing $20 \mathrm{~mm}$ dithiothreitol, separated on $8 \%$ SDS-PAGE, transferred to nitrocellulose membrane, immunoblotted, and revealed by ECL (GE Healthcare). The following primary antibodies were used: rabbit polyclonal anti-mGlu5 receptors (1:1000; Millipore Biotechnology); rabbit polyclonal anti-ephrin-B2 antibody (1:100, R\&D Systems); and rabbit polyclonal anti-KCC2 antibodies (Millipore Biotechnology). The hippocampus of mGlu5 receptor knock-out mice (Battaglia et al., 2004) was used to confirm the specificity of the anti-mGlu5 receptor antibody. 
Assessment of ephrin-B2 activation in transfected HEK293 cells and hippocampal slices

Human embryonic kidney 293 (HEK293) cells were grown in DMEM containing L-alanyl-L-glutamine, $10 \%$ fetal bovine serum, and antibiotics (100 U/ml penicillin, $100 \mu \mathrm{g} / \mathrm{ml}$ streptomycin) on $10 \mathrm{~cm}$ diameter cell culture dishes at $37^{\circ} \mathrm{C}$ in an atmosphere of $5 \% \mathrm{CO}_{2}, 95 \%$ air. Transient transfection with ephrin-B2 construct (gift from Dr. Wilkinson, London) was performed using Lipofectamine 2000 in OptiMEM medium (Invitrogen) and $10 \mu \mathrm{g}$ of cDNA for $4 \mathrm{~h}$. The cells were serum starved overnight and then treated for $30 \mathrm{~min}$ with either clustered EphB1/Fc $(0.25 \mu \mathrm{g} / \mathrm{ml})$, unclustered EphB1/Fc or the anti-Fc IgG alone. Neonate hippocampal slices, prepared using the same method described for the assessment of PI hydrolysis, were preincubated in oxygenated Krebs/ Henseleit buffer, $\mathrm{pH}$ 7.4, for $90 \mathrm{~min}$, and then challenged with clustered EphB1/Fc, DHPG, MPEP, clustered EphB1/Fc + DHPG, or clustered EphB1/Fc + MPEP for $5 \mathrm{~min}$. A mixture of tyrosine phosphatase inhibitors (cocktail 2, Sigma-Aldrich) was added 15 min before drug addiction.

Total protein extracts $(1 \mathrm{mg}$ ) from HEK cells or hippocampal slices were immunoprecipitated as described previously (Calò et al., 2005). Briefly, we used $5 \mu \mathrm{g}$ of anti-ephrin-B2 antibody (Santa Cruz Biotechnology) for $4 \mathrm{~h}$ at $4^{\circ} \mathrm{C}$ followed by addition of $50 \mu \mathrm{l}$ of Protein-A Sepharose for $2 \mathrm{~h}$ at $4^{\circ} \mathrm{C}$. Ephrin-B2 immunoprecipitates were analyzed by immunoblotting with monoclonal 4G10 anti-phosphotyrosine antibody (Millipore Biotechnology) or anti-ephrin-B2 antibody (1:100, R\&D Systems).

\section{Results}

Low concentrations of the group-I mGlu receptor agonist, DHPG, induced short-term depression (STD) of Schaffer collateral/CA1 pyramidal cell synaptic transmission in adult and neonatal hippocampal slices

We recorded synaptic responses at Schaffer collateral-CA1 pyramidal cell synapses in hippocampal slices prepared from postnatal day 7-9 or from adult rats. In control slices, synaptic activity was stable for at least $3 \mathrm{~h}$ (data not shown). We challenged the slices with DHPG at concentrations of $10 \mu \mathrm{M}$ to induce a transient depression of synaptic transmission. Lower concentrations of DHPG $(5 \mu \mathrm{M})$ did not affect synaptic transmission (data not shown; see also van Dam et al., 2004), whereas higher concentrations $(20-50 \mu \mathrm{M})$ are known to induce postsynaptic depolarization (Davies et al., 1995) and nondecremental LTD (Palmer et al., 1997; Fitzjohn et al., 1999). In adult hippocampal slices, bath application of $10 \mu \mathrm{M}$ DHPG for 20 min induced a short-term depression (STD) of synaptic activity (from 18 to $42 \%$ below the baseline in different experiments) that returned back to baseline levels $30 \mathrm{~min}$ following washout of DHPG (Fig. $1 \mathrm{~A}$ ). Similarly, in neonatal hippocampal slices, DHPG application resulted in STD, which returned to baseline following drug withdrawal (Fig. 2A). Delivering paired stimulation showed no changes in paired-pulse facilitation (data not shown) indicating that expression of DHPG-induced STD was unlikely to be due to changes in neurotransmitter release.

Activation of ephrin-Bs induced a slight but nondecremental depression of synaptic transmission in hippocampal slices Membrane anchored ephrin ligands form a tetrameric complex with two molecules of cognate Eph receptors expressed by opposing cells. This complex generates forward and reverse signals bidirectionally in the two cells via phosphorylation processes (Himanen et al., 2004). We mimicked the physiological activation of ephrin-Bs by their receptors in vitro by using a soluble chimeric EphB1 receptor fused to the Fc portion of IgG, preclustered by an anti Fc antibody (Davis et al., 1994, Himanen et al., 2001). Clustered EphB1/Fc activated ephrin-B2 expressed in HEK293 cells, as detected by immunoblotting with antiphospho-tyrosine antibodies in ephrin-B2 immunoprecipitates (densitometric values of phosphorylated ephrin-B2/total ephrin$\mathrm{B} 2=$ controls $0.33 \pm 0.09$; clustered EphB1/Fc, $0.25 \mu \mathrm{g} / \mathrm{ml}=$ $0.65 \pm 0.11^{\star}$; unclustered Eph/Fc, $0.25 \mu \mathrm{g} / \mathrm{ml}=0.24 \pm 0.07$; anti-Fc IgG alone $=0.36 \pm 0.08$; means + SEM of 4 determinations; ${ }^{\star} p<0.05$ vs all other values). Perfusion of hippocampal slices with EphB1/Fc alone $(0.25 \mu \mathrm{g} / \mathrm{ml})$ induced a small depression of synaptic activity in both adult and postnatal hippocampal slices (Figs. $1 B$ and $2 B$, respectively). In contrast to the effects of DHPG, synaptic depression persisted after removal of EphB/Fc in adults and postnatal rats, respectively (Figs. $1 B, 2 B$ ). The anti-Fc antibody alone $(111 \mathrm{ng} / \mathrm{ml})$ had no effect on synaptic transmission (data not shown).

\section{Synaptic depression induced by either DHPG or activated ephrin-Bs was mediated by mGlu5 receptors}

To examine which of the two group-I mGlu receptor subtypes mediated DHPG-induced STD, we used CPCOOEt $(30 \mu \mathrm{M})$ and MPEP $(10 \mu \mathrm{M})$, which are noncompetitive antagonists of mGlu1 and mGlu5 receptors, respectively (Gasparini et al., 1999; Litschig et al., 1999; Pagano et al., 2000), and did not induce changes in synaptic transmission on their own (data not shown). DHPGinduced STD was completely prevented by the application of MPEP in both adult and neonatal hippocampal slices (Figs. 1C, $2 C)$, whereas CPCCOEt had no effect on DHPG-induced STD (Figs. 1D, 2D). We then combined either CPCCOEt or MPEP with EphB1/Fc to disclose a potential role for mGlu1 or mGlu5 receptors in synaptic depression induced by activated ephrin-Bs. Interestingly, synaptic depression induced by EphB1/Fc was abolished in the presence of MPEP (Figs. 1E, 2E) whereas it persisted in the presence of CPCCOEt (Figs. $1 F, 2 F$ ). Thus, synaptic changes induced by $\mathrm{EphB} 1 / \mathrm{Fc}$ required the endogenous activity of mGlu5 receptors.

\section{Robust and nondecremental synaptic depression induced by a combined activation of ephrin-Bs and mGlu5 receptors in hippocampal slices}

In this particular set of experiments, adult or neonate hippocampal slices were treated with clustered EphB1/Fc for $80 \mathrm{~min}$. DHPG was present in the last $20 \mathrm{~min}$ of EphB1/Fc exposure. Coapplication of DHPG with clustered EphB1/Fc resulted in LTD of synaptic transmission, which persisted for the entire recording period (140 $\mathrm{min})$. In addition, the extent of synaptic depression was much greater than that induced by DHPG of EphB1/Fc alone in both adult and neonate hippocampal slices (Figs. $1 G, 2 G$ ). The enhanced depression induced by DHPG and EphB1/Fc was completely dependent on activation of mGlu 5 receptors because synaptic depression returned back to baseline values when MPEP was present during the 20 min exposure to DHPG (Figs. $1 \mathrm{H}, 2 \mathrm{H}$ ).

\section{Responses to DHPG were specifically amplified by activated ephrin-Bs}

To examine whether the action of clustered EphB1/Fc was specific, we also challenged neonate hippocampal slices with unclustered EphB1/Fc or with clustered EhpA1/Fc. Unclustered EphB1/Fc is unable to activate ephrin-Bs (see above) and can even antagonize endogenous activation of ephrin-Bs in some studies (Davis et al., 1994). Addition of unclustered EphB1/Fc to hippocampal slices had no effect on synaptic transmission and did not change responses to $10 \mu \mathrm{M}$ DHPG (Fig. 2 J, K). Clustered EphA1/Fc, which selectively activates ephrin-As, did not mimic the action of clustered EphB1/Fc, but, unexpectedly, induced a 
A

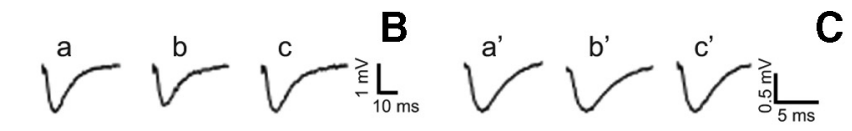

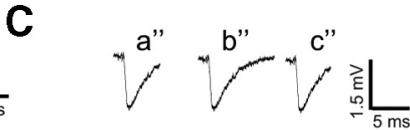

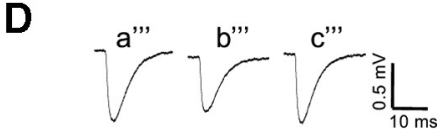

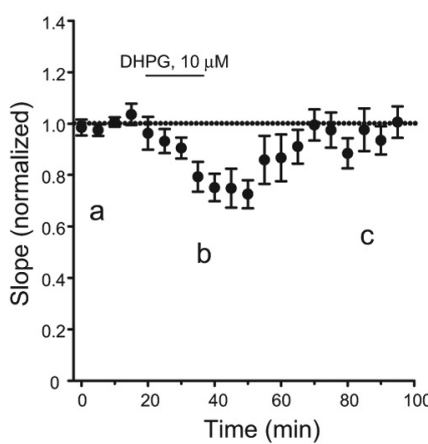

E
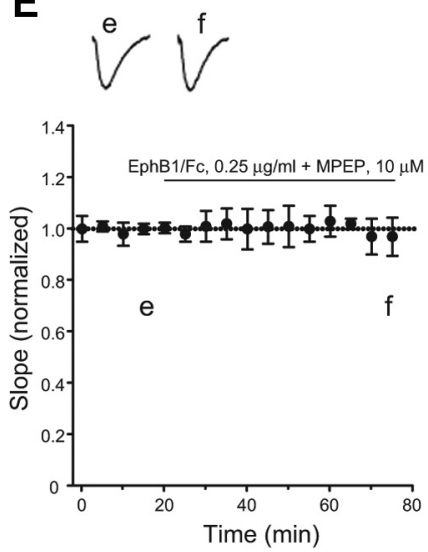

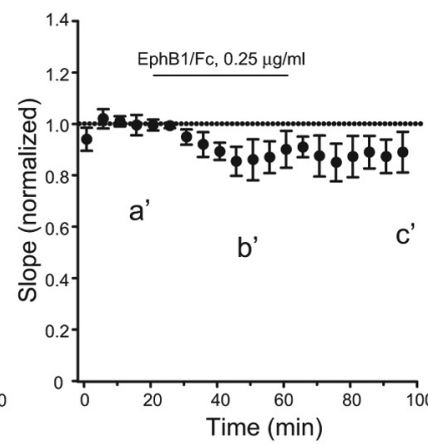

$\mathbf{F}$
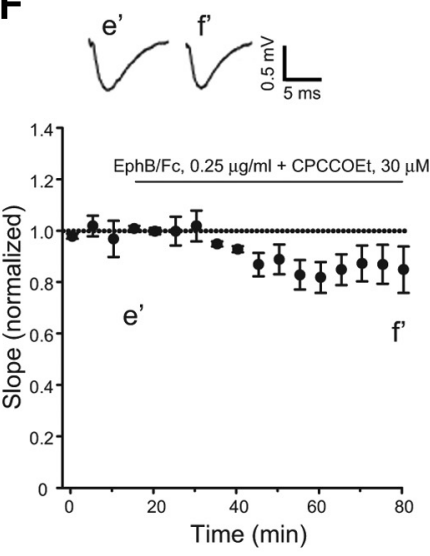

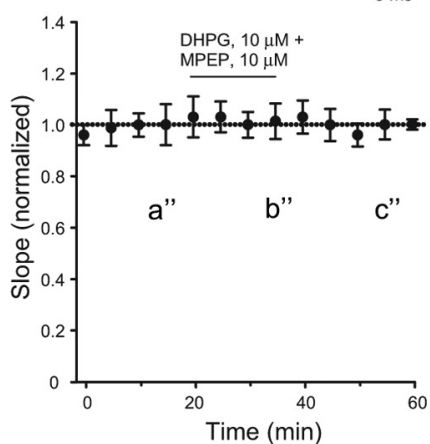

G
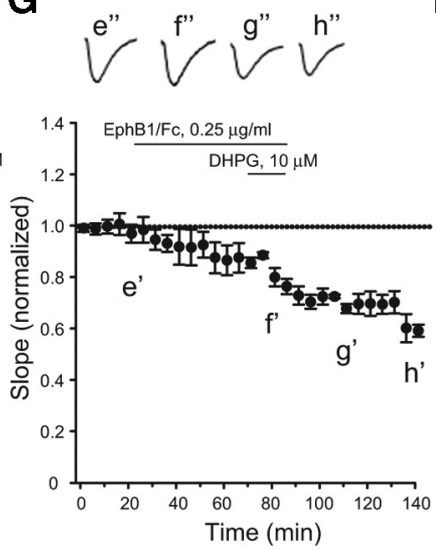

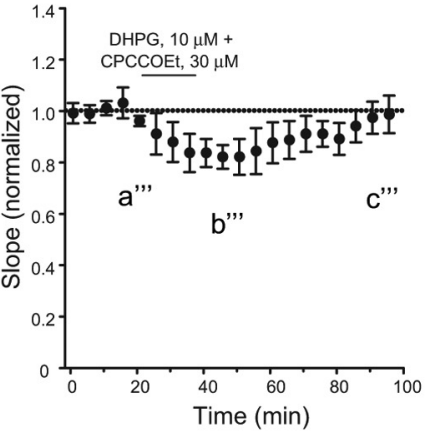

H
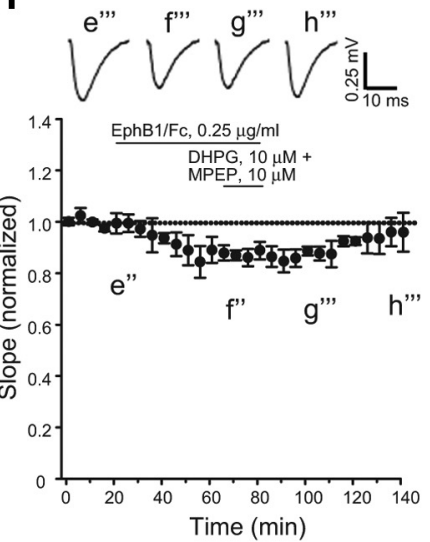

Figure 1. Pharmacological activation of $\mathrm{mGlu} 5$ receptors and ephrin-Bs depresses synaptic transmission at the Schaffer collateral/CA1 synapses in adult rat hippocampal slices. Pooled data normalized to the baseline, illustrating the effects of DHPG $(\boldsymbol{A})$, clustered EphB1/FC $(\boldsymbol{B}), \mathrm{DHPG}+\operatorname{MPEP}(\boldsymbol{C}), \mathrm{DHPG}+\mathrm{CPCCOEt}(\boldsymbol{D})$, clustered EphB1/FC + MPEP $(\boldsymbol{E})$, clustered EphB1/FC + $\mathrm{CPCCOEt}$ $(\boldsymbol{F})$, clustered EphB1/Fc + DHPG $(\boldsymbol{G})$, and clustered EphB1/Fc + DHPG + MPEP $(\boldsymbol{H})$ on the slope of fEPSP are shown. Values are means \pm SEM. Statistical analysis was performed by one-way ANOVA followed by Tukey's PLSD. In $\boldsymbol{A}(n=5)$, values corresponding to the peak of synaptic depression ( $40-60 \mathrm{~min}$ ) were significantly different from baseline values $(p<0.05)$; in $\boldsymbol{B}(n=6)$, all values following the termination of Eph/Fc exposure were significantly different from baseline values $(p>0.05)$ except the value at time 0 ; in $C(n=3)$, none of the values with DHPG + MPEP differed from baseline values; in $\boldsymbol{D}(n=3)$, peak values of synaptic depression ( $40-50 \mathrm{~min})$ were significantly different from baseline values $(p<0.05)$; in $\boldsymbol{E}(n=3)$, none of the values with EphB1/Fc + MPEP differed from baseline values; in $\boldsymbol{F}(n=5)$, peak values of synaptic depression ( $40-60 \mathrm{~min})$ were significantly different from the two initial baseline values; in $\boldsymbol{G}$, $(n=6)$ note a robust nondecremental LTD induced by coapplication of EphB1/Fc and DHPG. DHPG was applied for 20 min following a 60 min exposure to EphB1/Fc. All values recorded at the end of DHPG exposure were significantly different from values recorded during exposure to EphB1/Fc alone $(p<0.05)$. Note in $\boldsymbol{H}(n=5)$ that the synergism between EphB1/Fc and DHPG was abolished when DHPG was applied in the presence of MPEP. Representative traces illustrating fEPSP before, during, and after drug applications are shown in all figures. Traces are averages of four consecutive responses at the indicated time points.

long-lasting increase in synaptic transmission (Fig. 2L). DHPG was still able to reduce synaptic transmission when combined with clustered EphA1/Fc (Fig. 2M).

\section{Measurements of intracellular signaling pathways in} hippocampal slices challenged with DHPG and/or EphB1/Fc Using hippocampal tissue from 7 - to 9-d-old rats we confirmed that mGlu5 receptors coimmunoprecipitates with ephrin-B2 (Calò et al., 2005). We used a polyclonal antibody that recognizes a $\mathrm{C}$ terminus epitope of mGlu5 receptors. The antibody labeled a major band at $140 \mathrm{kDa}$, which is the expected molecular size of the mGlu5 receptor monomers, and an additional high molecular weight band, which may correspond to receptor dimers. Both bands were absent in the hippocampus of mGlu5 receptor knockout mice (Fig. 3A). The input rat hippocampal tissue used for immunoprecipitation expressed mGlu5 receptors, ephrin-B2, and the neuronal $\mathrm{K}^{+} / \mathrm{Cl}^{-}$cotransporter, KCC2. Ephrin-B2 and KCC2 were detected as single bands at the expected molecular size of 37 and $140 \mathrm{kDa}$, respectively. The mGlu5 receptor was detected in ephrin-B2 immunoprecipitates, but not in KCC2 im- munoprecipitates (negative controls) (Fig. 3A). We then examined whether activation of ephrin-B2 by clustered EphB1/Fc potentiated the stimulation of PI hydrolysis by DHPG in neonatal hippocampal slices. In neonatal brain tissue, the PI response to DHPG and other group-I mGlu receptor agonists is substantial and largely mediated by mGlu5 receptors (Nicoletti et al., 1986; Casabona et al., 1997). DHPG produced a $>3$-fold increase in PI hydrolysis at $10 \mu \mathrm{M}$ (Fig. 3B), and a tenfold increase at $100 \mu \mathrm{M}$ (data not shown). The action of DHPG was inhibited by MPEP but not CPCCOEt (Fig. 3B). Clustered EphB1/Fc alone had no effect on $\left[{ }^{3} \mathrm{H}\right]$ InsP formation (Fig. $3 C$ ), excluding a direct interaction of the chimeric protein with mGlu5 receptors. However, clustered EphB1/Fc amplified the stimulation of PI hydrolysis by $10 \mu \mathrm{M}$ DHPG, and this potentiation was abolished by MPEP (Fig. $3 C$ ). We then examined whether drugs that bind to mGlu5 receptors (i.e., DHPG or MPEP) could influence the activation of ephrin-B2, as assessed by immunoblot analysis of phosphorylated ephrin-B2 in response to clustered EphB1/Fc. Clustered EphB1/Fc increased tyrosine phosphorylation in ephrin-B2 immunoprecipitates from neonate hippocampal slices. This effect 


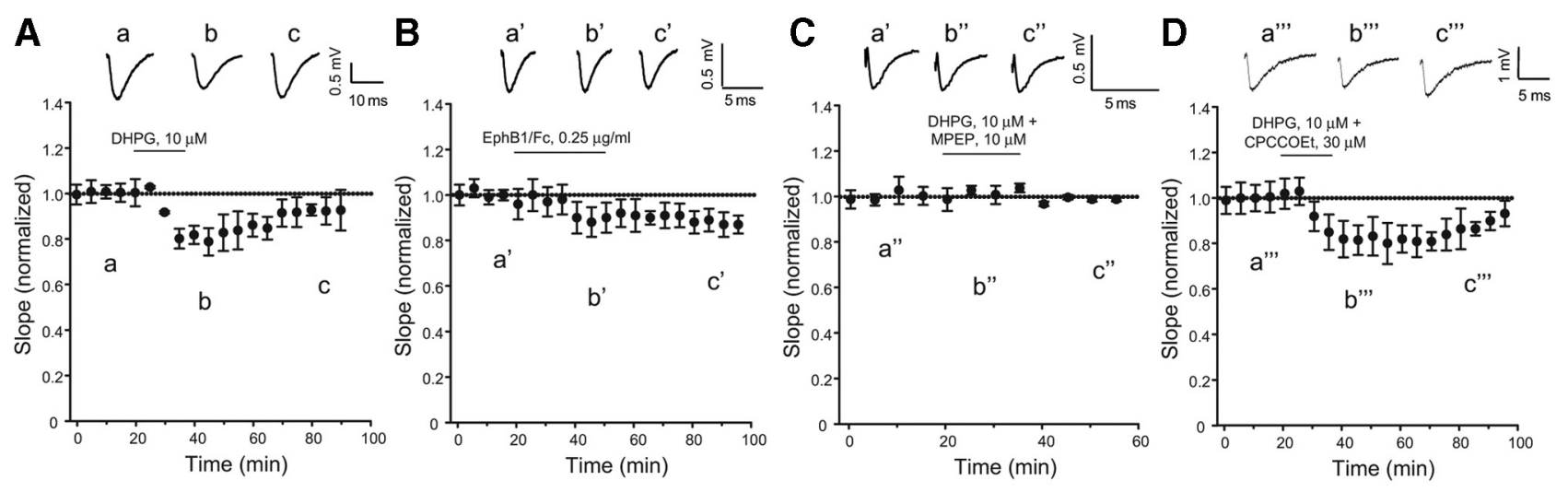

E
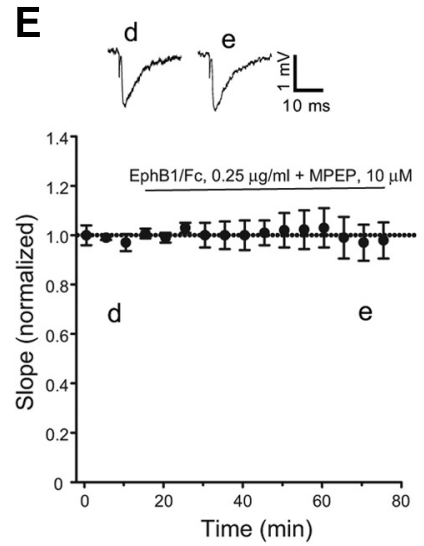

$\mathbf{F}$

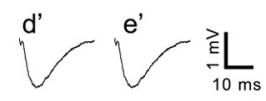

G

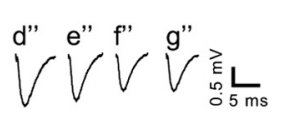

H
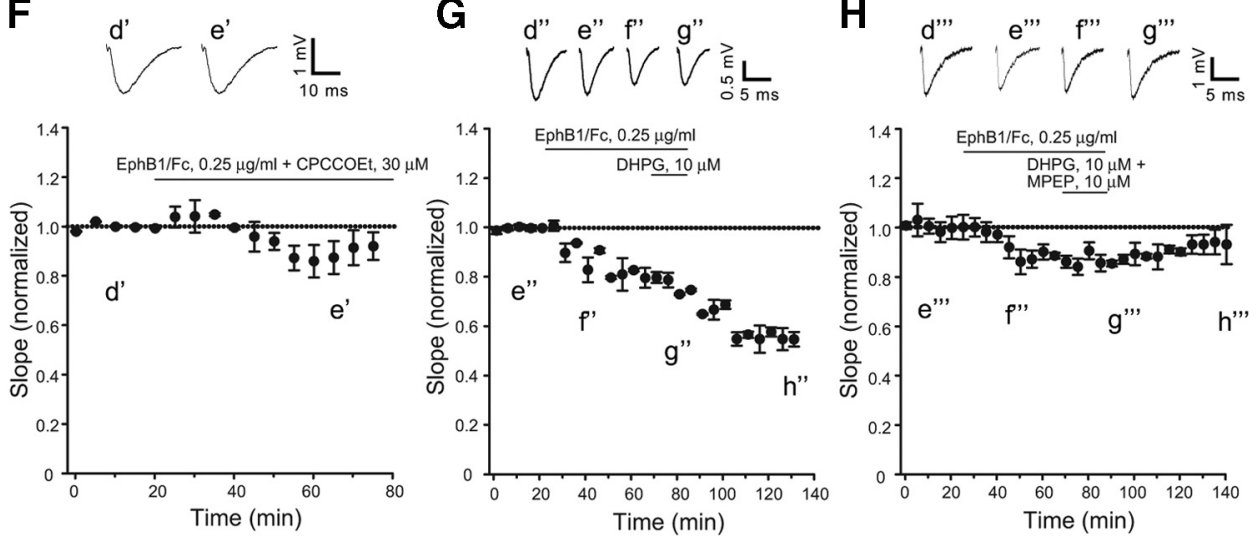

$\mathbf{K}$
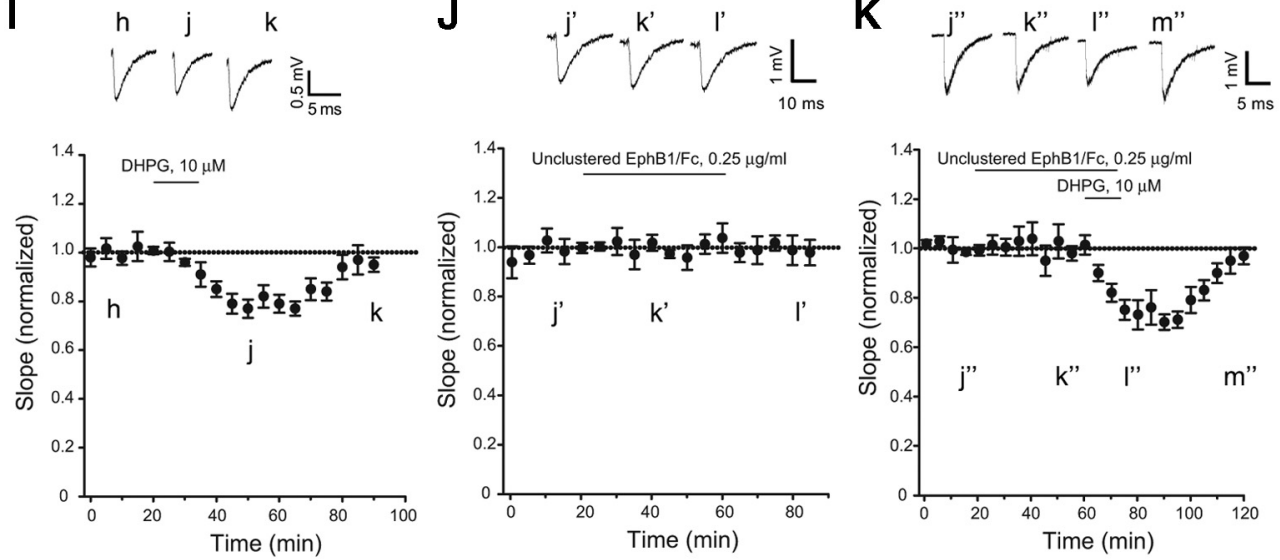

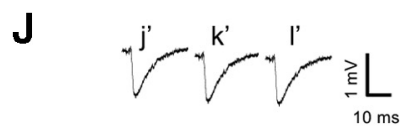
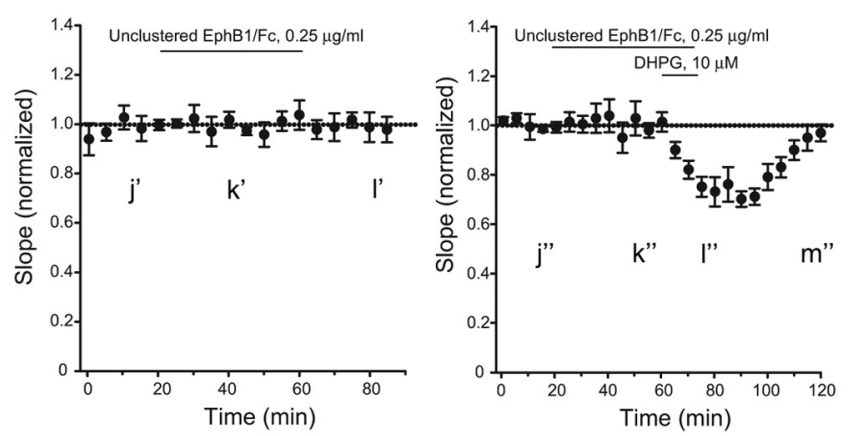

L

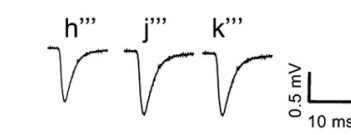<smiles>[M][C]1[In]CCC[I-]1</smiles>

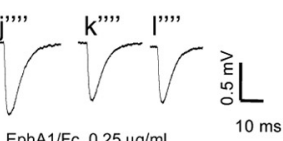
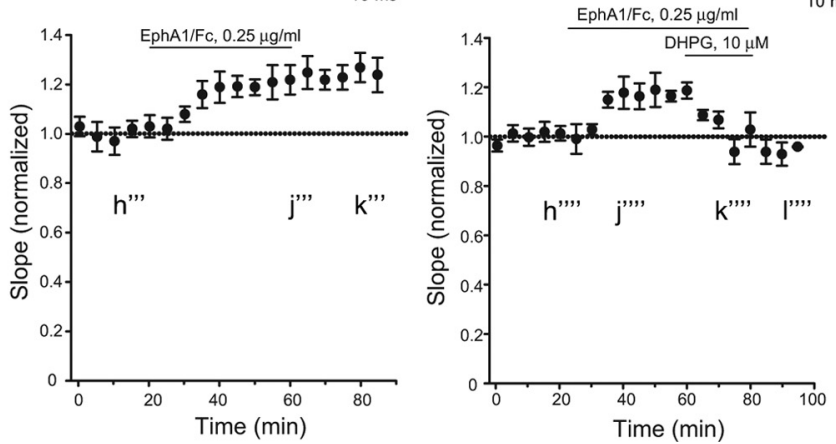

Figure 2. Same as in Figure 1, but in hippocampal slices from rats at postnatal days $7-9$. In $A$ and $\boldsymbol{D}$ ( $n=6$ and 4 , respectively), values corresponding to the peak of synaptic depression ( $40-60$ min) were significantly different from baseline values ( $p<0.05)$; in $\boldsymbol{B}(n=5)$, values following the termination of Eph/Fcexposure were significantly different from baseline values $(p<0.05)$; in $\boldsymbol{F}(n=5)$, values from 50 to 60 min were significantly different from baseline values $(p<0.05)$; in Cand $\boldsymbol{E}(n=4$ and 5 , respectively), none of the values with DHPG + MPEP or clustered EphB1/Fc $+($ Figure legend continues.) 
was abolished by MPEP (Fig. 3D), suggesting that ephrin-B2 phosphorylation in response to clustered EphB1/Fc requires the presence of endogenously active mGlu5 receptors. DHPG had no effect on ephrin-B2 phosphorylation when applied alone or in combination with clustered EphB1/Fc (Fig. $3 D$ ). We also examined the activation of the MAPK and the PI-3-K pathways in neonate hippocampal slices challenged with DHPG and/or clustered EphB1/Fc. Immunoblot analysis of phosphorylated ERK1/2 showed that DHPG produced a slight concentration-dependent activation of the MAPK pathway. Clustered EphB1/Fc was inactive on its own and did not potentiate the action of $10 \mu \mathrm{M}$ DHPG (Fig. 4A). The MAPKK (MEK) inhibitor, UO126, inhibited the short-term depression of synaptic transmission induced by $10 \mu \mathrm{M}$ DHPG. A nonsignificant trend to a long last depression of synaptic transmission was induced clustered EphB1/Fc in the presence of UO126. When applied together in the presence of UO126, clustered EphB1/Fc and DHPG induced responses similar to those induced by clustered EphB1/Fc alone (Fig. $4 B-D)$. Neither DHPG nor EphB1/Fc had any detectable effect on the PI-3-K pathway, as detected by immunoblot analysis of phosphorylated Akt (Fig. 5A). The PI-3-K inhibitor, LY294002, did not affect the depression of synaptic transmission induced by DHPG and/or clustered EphB1/Fc (Fig. 5B-D).

\section{Discussion}

mGlu receptor-dependent LTD in the CA1 region can be induced by particular stimulation protocols (e.g., by paired-pulse lowfrequency stimulation; PP-LSF) or, alternatively, by direct application of group-I mGlu receptor agonists to hippocampal slices (Fitzjohn et al., 1996; Overstreet et al., 1997; Palmer et al., 1997; Schnabel et al., 1999; Huber et al., 2000). The latter strategy carries the advantage of selectively activating group-I mGlu receptors, although it should be kept in mind that there may be some differences in the molecular events underlying the induction and expression of DHPG/LTD and PP-LFS-induced mGlu receptor-

$\leftarrow$

(Figure legend continued.) MPEP differed from baseline values; in $\mathbf{G}(n=5)$, we found the same synergism between EphB1/Fc and DHPG observed in adult hippocampal slices (see Fig. $1 G)$. All values recorded at the end of DHPG exposure were significantly different from values recorded during exposure to EphB1/Fc alone $(p<0.05)$. Again, the synergism between EphB1/Fc and DHPG was abolished when DHPG was applied in the presence of MPEP $(n=5)$. Pool data from a different set of experiments with hippocampal slices from rats at postnatal days 7-9 are shown in $\boldsymbol{I}-\boldsymbol{M}$. $\operatorname{In} \boldsymbol{I}(\mathrm{DHPG} ; n=5$ ) and $\boldsymbol{K}$ (unclustered EphB1/Fc $+\mathrm{DHPG} ; n=5$ ), values corresponding to the peak of synaptic depression (from 40 to $80 \mathrm{~min}$ in I and from 79 to $110 \mathrm{~min}$ in $\boldsymbol{K}$ ) were significantly different from baseline values $(p<0.05)$; the lack of effect of unclustered EphB1/Fc on synaptic transmission is shown in $J(n=6)$; in $\boldsymbol{L}(n=6)$, clustered EphA1/Fc is shown to induce a long-lasting increase in synaptic transmission. Values at times $>40$ min are significantly different from baseline values; in $\boldsymbol{M}(n=5)$, DHPG is still able to reduce synaptic transmission in the presence of clustered EphA1/Fc. Representative traces illustrating fEPSP are shown in all figures. Traces are averages of four consecutive responses at the indicated time points.

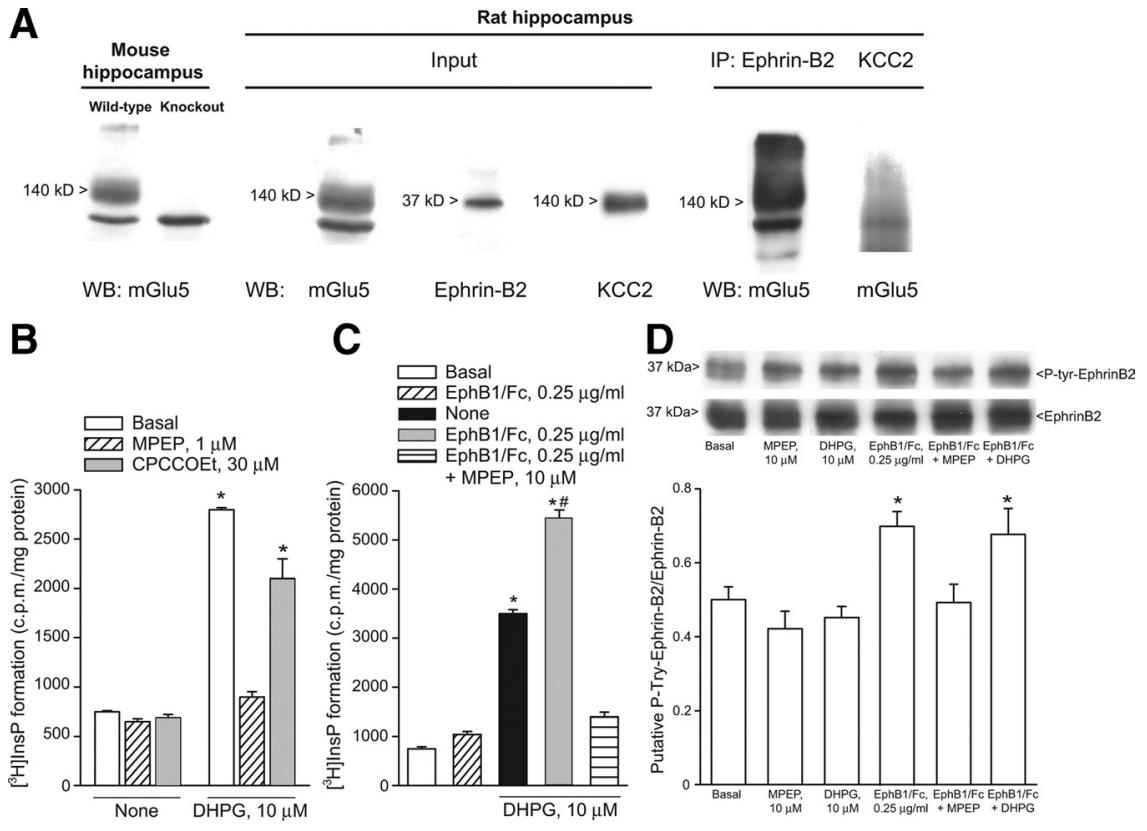

Figure 3. A, mGlu5 receptors coimmunoprecipitate with ephrin-B2 in hippocampal protein extracts. From the left side: (1) WB, Western blotting. B, C, Stimulation of PI hydrolysis in neonate hippocampal slices challenged with DHPG $(10 \mu \mathrm{M})$ in the , respectively. Data are means - SEM of 5-6 determinations. $p<0.05$ ((one-way ANOVA + Tukey's PLSD) vs the alone or in combination is shown in $\boldsymbol{D}$. Data were normalized by the levels of total ephrin-B2 in immunoprecipitates. Densitometric values are means \pm SEM of $4-5$ determinations. ${ }^{*} p<0.05$ (one-way ANOVA + PLSD vs control values).

dependent LTD (reviewed by Kemp and Bashir, 2001). In our experiments, application of $10 \mu \mathrm{M}$ DHPG to hippocampal slices induced STD of excitatory synaptic transmission at the Schaffer collateral/CA1 pyramidal cell synapses. STD was entirely mediated by the activation of mGlu5 receptors because it was abolished by the noncompetitive mGlu5 receptor antagonist, MPEP, but not by the mGlu1 receptor antagonist, CPCCOEt. mGlu5 receptors are predominantly, if not exclusively, localized to postsynaptic elements in the hippocampus (Shigemoto et al., 1997). To examine whether DHPG-induced synaptic depression was modulated by the ephrin/Eph receptor system, we focused on ephrin-Bs, which are also postsynaptically localized in CA1 pyramidal cells (Grunwald et al., 2004; Rodenas-Ruano et al., 2006). Pharmacological activation of ephrin-Bs by means of a preclustered $\mathrm{EphB} 1$ receptor/Fc chimera, induced a small but longlasting depression of synaptic transmission, in contrast to the STD induced by DHPG. This effect was specific because no depression of synaptic transmission was seen in slices treated with unclustered $\mathrm{EphB} 1 / \mathrm{Fc}$, the anti-Fc antibody alone, or clustered EphA1/Fc. In contrast, clustered EphA1/Fc, which selectively activates ephrin-As, induced a long-lasting increase in synaptic transmission, an unexpected finding that warrants further investigation. Interestingly, both the slight depression of synaptic transmission and the increase in ephrin-B2 phosphorylation induced by clustered EphB1/Fc were prevented by MPEP, suggesting that $\mathrm{mGlu} 5$ receptors are involved in the activation process of ephrin-B2. It is unlikely that clustered EphB1/Fc directly activated mGlu5 receptors because clustered EphB1/Fc failed to stimulate PI hydrolysis in neonate hippocampal slices, i.e., in a 
A

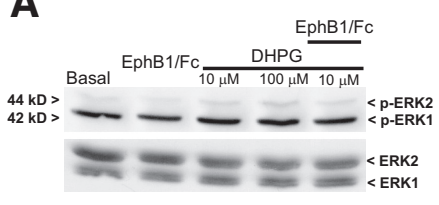

B

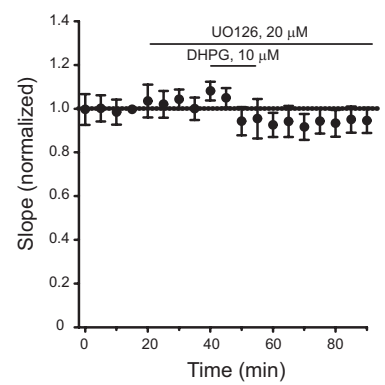

C

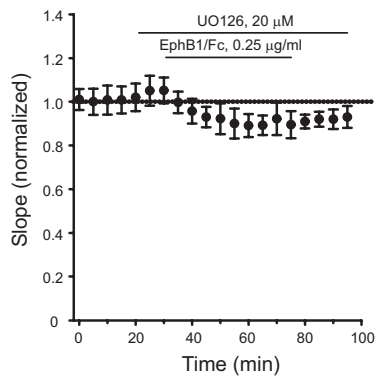

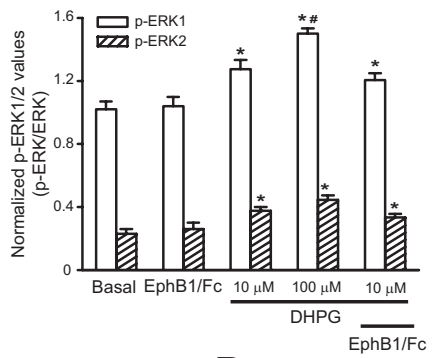

D

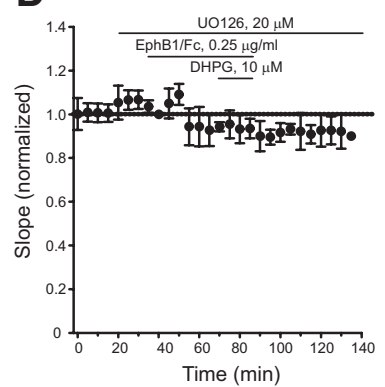

Figure 4. A, ERK1/2 phosphorylation in neonate hippocampal slices challenged with DHPG and clustered EphB1/Fc applied alone or in combination. Note that DHPG induced a slight a concentration-dependent activation of the MAPK pathway, whereas clustered EphB1/Fc was inactive. Values are means \pm SEM of four determinations. $p<0.05$ (one-way ANOVA + Tukey's PLSD) vs controls (*) or $10 \mu \mathrm{M} D H P G(\#)$. The effect of DHPG, clustered EphB1/Fc, and DHPG + clustered EphB1/Fc in neonate hippocampal slices treated with the MEK inhibitor, U0126, is shown in $\boldsymbol{B}-\boldsymbol{D}$, respectively (values are means + SEM of 4-5 determinations).

A
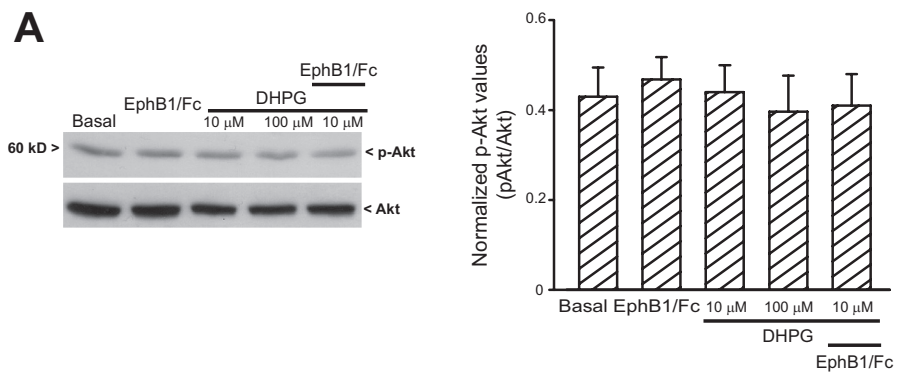

B

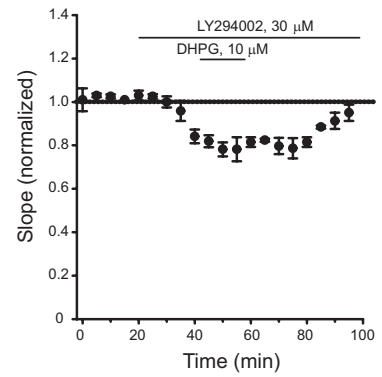

C

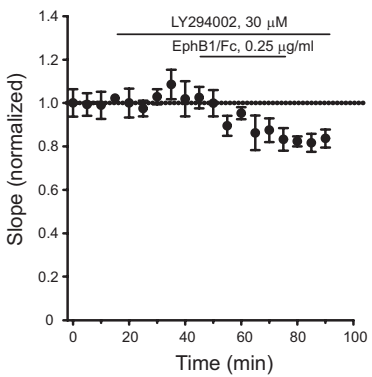

D

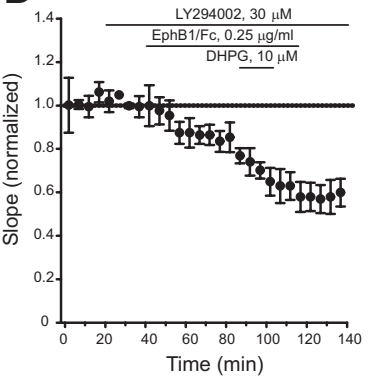

Figure 5. A, Akt phosphorylation in neonate hippocampal slices challenged with DHPG and clustered EphB1/Fc applied alone or in combination. Note that neither DHPG nor clustered EphB1/Fc activated the PI-3-K pathway. The effect of DHPG, clustered EphB1/Fc, and DHPG + clustered EphB1/Fc in neonate hippocampal slices treated with the PI-3-Kinhibitor, LY294002, is shown in $\boldsymbol{B}-\boldsymbol{D}$, respectively. Vales are means \pm SEM. $\ln \boldsymbol{B}(n=4)$, values from 40 to 80 min were significantly different from baseline values $p<0.05$ (one-way ANOVA + Tukey's PLSD); in $C(n=5)$, values $>70$ min were significantly different from baseline values $(p<$ 0.05 ); in $D$, the synergism between clustered EphB1/Fc and DHPG persists in the presence of $L Y 294002$. Values from 100 to 140 min were significantly different from values obtained with clustered EphB1/Fc alone $(p<0.05)$ (all points in the presence of LY294002).

system in which mGlu5 receptors are highly responsive to pharmacological activation (Nicoletti et al., 1986). It is possible that ephrin-Bs and mGlu5 are functionally interconnected in the same synaptic territory, and an active conformation of mGlu5 receptors enables the activation of ephrin-B2. MPEP could impair this process by inhibiting the activation of mGlu5 receptors

by endogenous glutamate or the consititutive activity of mGlu5 receptors (Joly et al., 1995; Ango et al., 2001; Mühlemann et al., 2005). If so, how can we explain the difference between synaptic depression induced by ephrin-B activation and DHPGinduced STD? One possibility is that EphB1/Fc tightly binds to ephrin-Bs and is not easily washed out, as opposed to DHPG. An alternative explanation, which we favor, is that synaptic depression induced by ephrin-B activation incorporates at least two components: (1) a necessary component mediated by mGlu5 receptors; and (2) an additional component intrinsic to ephrin-B signaling and independent of mGlu5 receptors. Activated ephrins trigger a cascade of phosphorylation processes mediated by soluble tyrosine kinases (see Introduction and references therein). Tyrosine phosphorylation is known to affect AMPA receptor trafficking and responses, thereby influencing the efficacy of excitatory synaptic transmission (Wang et al., 2005; Moult et al., 2006). The intrinsic ephrin-B component might be critical for the duration of synaptic depression providing that mGlu5 receptors are endogenously activated (or constitutively active). When combined with low concentrations of DHPG (here, $10 \mu \mathrm{M}$ ), activation of ephrin-Bs by clustered EphB1/Fc amplified the stimulation of PI hydrolysis and generated a robust and nondecremental synaptic depression similar to that typically observed with higher concentrations of DHPG. Unclustered EphB1/Fc did not produce such an effect. It should be highlighted that in some studies unclustered EphB1/Fc inhibits the endogenous activation of ephrin-Bs (Davis et al., 2004). If so, data with unclustered EphB1/Fc in our study might suggest the absence of a constitutive regulation of synaptic transmission by endogenous ephrin-Bs. However, whether or not, and to what extent, unclustered EphB1/Fc at concentrations of $0.25 \mu \mathrm{g} / \mathrm{m}$ blocks endogenous ephrin-Bs in hippocampal slices is uncertain, and there might be a threshold for the regulation of synaptic transmission by endogenous ephrin-Bs. Accurate titration studies with unclustered $\mathrm{EphB} 1 / \mathrm{Fc}$ are needed to solve this caveat.

DHPG-induced LTD at the Schaffer collateral-CA1 synapses is insensitive to inhibitors of phospholipase $C \beta$ (Huang and $\mathrm{Hsu}, 2006$ ), inhibitors of protein kinase C (Schnabel et al., 1999), intracellular $\mathrm{Ca}^{2+}$ chelators (Fitzjohn et al., 2001; Ireland and Abraham, 2009), or agents that deplete intracellular $\mathrm{Ca}^{2+}$ stores (Schnabel et al., 1999). Thus, it is unlikely that amplification of PI hydrolysis mediates the synergism between clustered EphB1/Fc and DHPG on synaptic depression. Activation of the MAPK pathway and the $\mathrm{PI}-3-\mathrm{K} / \mathrm{Akt} / \mathrm{mammalian}$ target of rapamycin (mTOR) pathway 
has been implicated in the induction of LTD by DHPG at the Schaffer collateral-CA1 synapses (Gallagher et al., 2004; Hou and Klann, 2004; Banko et al., 2006; Volk et al., 2006; Ronesi and Huber, 2008). In neonate hippocampal slices, DHPG activated the MAPK pathway but not the PI-3-K pathway, and DHPG failed to induce STD in the presence of the MEK inhibitor, UO126. Under our conditions, clustered EphB1/Fc did not activate the MAPK and PI-3-K pathways. In addition, clustered EphB1/Fc still induced LTD in the presence of the PI-3-K inhibitor, LY49002, and induced a trend to a long-lasting depression of synaptic transmission in the presence of the MEK inhibitor, UO126. It should be highlighted that multiple signaling pathways contribute to DHPG-induced synaptic depression at the Schaffer collateral-CA1 synapses, including activation of c-Jun N-terminal kinases (Li et al., 2007), p38 MAPK (Rush et al., 2002), nuclear factor $\kappa \mathrm{B}$ (O’Riordan et al., 2006), tyrosine dephosphorylation (Moult et al., 2002, 2006; Gladding et al., 2009). Which of these pathways mediates the synergism between ephrin-B2 and mGlu5 receptors on synaptic transmission remains to be determined.

One of the most interesting findings in the mGlu receptor field is that an exaggerated signaling through mGlu5 receptors can account for a variety of symptoms associated with fragile $\mathrm{X}$ syndrome, the most common form of heritable mental retardation and the leading identified cause of autism (reviewed by Bear et al., 2004; Dölen and Bear, 2008). LTD triggered by activation of mGlu5 receptors is selectively enhanced in the hippocampus of mice lacking the fragile $\mathrm{X}$ mental retardation protein (Huber et al., 2002; Nosyreva and Huber, 2006; Nakamoto et al., 2007; Park et al., 2008). Furthermore, either mGlu5 receptor antagonists or a genetic reduction in the expression of mGlu 5 receptors rescue the fragile X phenotype in these mice (Bear, 2005; Dölen and Bear, 2005; Yan et al., 2005; Dölen et al., 2007). Our finding that activated ephrin-Bs cooperate withmGlu5 receptors for the induction of synaptic depression encourages the study of the ephrin/ Eph receptor system in mouse models of fragile $\mathrm{X}$, and raises the possibility that ephrins represent new targets for drugs that regulate mGlu5 receptor signaling in the hippocampus.

\section{References}

Ango F, Prézeau L, Muller T, Tu JC, Xiao B, Worley PF, Pin JP, Bockaert J, Fagni L (2001) Agonist-independent activation of metabotropic glutamate receptors by the intracellular protein Homer. Nature 41:962-965.

Anwyl R (1999) Metabotropic glutamate receptors: electrophysiological properties and role in plasticity. Brain Res Brain Res Rev 29:83-120.

Armstrong JN, Saganich MJ, Xu NJ, Henkemeyer M, Heinemann SF, Contractor A (2006) B-ephrin reverse signaling is required for NMDAindependent long-term potentiation of mossy fibers in the hippocampus. J Neurosci 26:3474-3481.

Banko JL, Hou L, Poulin F, Sonenberg N, Klann E (2006) Regulation of eukaryotic initiation factor $4 \mathrm{E}$ by converging signaling pathways during metabotropic glutamate receptor-dependent long-term depression. J Neurosci 26:2167-2173.

Battaglia G, Busceti CL, Molinaro G, Biagioni F, Storto M, Fornai F, Nicoletti F, Bruno V (2004) Endogenous activation of mGlu5 metabotropic glutamate receptors contributes to the development of nigro-striatal damage induced by 1-methyl-4-phenyl-1,2,3,6-tetrahydropyridine in mice. J Neurosci 28:828-835.

Bear MF (2005) Therapeutic implications of the mGluR theory of fragile X mental retardation. Genes Brain Behav 4:393-398.

Bear MF, Huber KM, Warren ST (2004) The mGluR theory of fragile X mental retardation. Trends Neurosci 27:370-377.

Bortolotto ZA, Fitzjohn SM, Collingridge GL (1999) Roles of metabotropic glutamate receptors in LTP and LTD in the hippocampus. Curr Opin Neurobiol 9:299-304.

Brückner K, Pasquale EB, Klein R (1997) Tyrosine phosphorylation of transmembrane ligands for Eph receptors. Science 275:1640-1643.

Brückner K, Pablo Labrador J, Scheiffele P, Herb A, Seeburg PH, Klein R
(1999) EphrinB ligands recruit GRIP family PDZ adaptor proteins into raft membrane microdomains. Neuron 22:511-524.

Calò L, Bruno V, Spinanti P, Molinari G, Korkhov V, Esposito Z, Patanè M, Melchiorri D, Freissmuth M, Nicoletti F (2005) Interactions between ephrin-B and metabotropic glutamate 1 receptors in brain tissue and cultured neurons. J Neurosci 25:2245-2254.

Calò L, Cinque C, Patanè M, Schillaci $\mathrm{D}$, Battaglia G, Melchiorri D, Nicoletti F, Bruno V (2006) Interaction between ephrins/Eph receptors and excitatory amino acid receptors: possible relevance in the regulation of synaptic plasticity and in the pathophysiology of neuronal degeneration. J Neurochem 98:1-10.

Casabona G, Knopfel T, Kuhn R, Baumann P, Sortino MA, Copani A, Nicoletti F (1997) Expression and coupling to polyphosphoinositide hydrolysis of group I metabotropic glutamate receptors in early postnatal and adult rat brain. Eur J Neurosci 9:12-17.

Cho K, Bashir ZI (2002) Cooperation between mGlu receptors: a depressing mechanism? Trends Neurosci 25:405-411.

Contractor A, Rogers C, Maron C, Henkemeyer M, Swanson GT, Heinemann SF (2002) Trans-synaptic Eph receptor-ephrin signaling in hippocampal mossy fiber LTP. Science 296:1864-1869.

Dalva MB, Takasu MA, Lin MZ, Shamah SM, Hu L, Gale NW, Greenberg ME (2000) EphB receptors interact with NMDA receptors and regulate excitatory synapse formation. Cell 103:945-956.

Davies CH, Clarke VR, Jane DE, Collingridge GL (1995) Pharmacology of postsynaptic metabotropic glutamate receptors in rat hippocampal CA1 pyramidal neurones. J Pharmacol 116:1859-1869.

Davis S, Gale NW, Aldrich TH, Maisonpierre PC, Lhotak V, Pawson T, Goldfarb M, Yancopoulos GD (1994) Ligands for EPH-related receptor tyrosine kinases that require membrane attachment or clustering for activity. Science 266:816-819.

Dölen G, Bear MF (2005) Courting a cure for fragile X. Neuron 45:753-764.

Dölen G, Bear MF (2008) Role for metabotropic glutamate receptor 5 (mGluR5) in the pathogenesis of fragile $\mathrm{X}$ syndrome. J Physiol 586:1503-1508.

Dölen G, Osterweil E, Rao BS, Smith GB, Auerbach BD, Chattarji S, Bear MF (2007) Correction of fragile X syndrome in mice. Neuron 56:955-962.

Fitzjohn SM, Irving AJ, Palmer MJ, Harvey J, Lodge D, Collingridge GL (1996) Activation of group I mGluRs potentiates NMDA responses in rat hippocampal slices. Neurosci Lett 203:211-213.

Fitzjohn SM, Kingston AE, Lodge D, Collingridge GL (1999) DHPGinduced LTD in area CAl of juvenile rat hippocampus; characterisation and sensitivity to novel mGlu receptor antagonists. Neuropharmacology 38:1577.

Fitzjohn SM, Palmer MJ, May JE, Neeson A, Morris SA, Collingridge GL (2001) A characterisation of long-term depression induced by metabotropic glutamate receptor activation in the rat hippocampus in vitro. J Physiol 537:421-430.

Flanagan JG, Vanderhaegen P (1998) The ephrin and Eph receptors in neural development. Annu Rev Neurosci 21:309-345.

Gallagher SM, Daly CA, Bear MF, Huber KM (2004) Extracellular signalregulated protein kinase activation is required for metabotropic glutamate receptor-dependent long-term depression in hippocampal area CA1. J Neurosci 24:4859-4864.

Gasparini F, Lingenhöhl K, Stoehr N, Flor PJ, Heinrich M, Vranesic I, Biollaz M, Allgeier H, Heckendorn R, Urwyler S, Varney MA, Johnson EC, Hess SD, Rao SP, Sacaan AI, Santori EM, Veliçelebi G, Kuhn R (1999) 2-Methyl-6-(phenylethynyl)-pyridine (MPEP), a potent, selective and systemically active mGlu5 receptor antagonist. Neuropharmacology 38:1493-1503.

Gladding CM, Collett VJ, Jia Z, Bashir ZI, Collingridge GL, Molnár E (2009) Tyrosine dephosphorylation regulates AMPAR internalisation in mGluR-LTD. Mol Cell Neurosci 40:267-279.

Grunwald IC, Korte M, Adelmann G, Plueck A, Kullander K, Adams RH, Frotscher M, Bonhoeffer T, Klein R (2004) Hippocampal plasticity requires postsynaptic ephrinBs. Nat Neurosci 7:33-40.

Himanen JP, Rajashankar KR, Lackmann M, Cowan CA, Henkemeyer M, Nikolov DB (2001) Crystal structure of an Eph receptor-ephrin complex. Nature 414:933-938.

Himanen JP, Chumley MJ, Lackmann M, Li C, Barton WA, Jeffrey PD, Vearing C, Geleick D, Feldheim DA, Boyd AW, Henkemeyer M, Nikolov DB (2004) Repelling class discrimination: ephrin-A5 binds to and activates EphB2 receptor signaling. Nat Neurosci 7:501-509. 
Holland SJ, Gale NW, Mbamalu G, Yancopoulos GD, Henkemeyer M, Pawson T (1996) Bidirectional signalling through the EPH-family receptor Nuk and its transmembrane ligands. Nature 383:722-725.

Hou L, Klann E (2004) Activation of the phosphoinositide 3-kinase-Aktmammalian target of rapamycin signaling pathway is required for metabotropic glutamate receptor-dependent long-term depression. J Neurosci 24:6352-6361.

Huang CC, Hsu KS (2006) Sustained activation of metabotropic glutamate receptor 5 and protein tyrosine phosphatases mediate the expression of (S)-3,5-dihydroxyphenylglycine-induced long-term depression in the hippocampal CA1 region. J Neurochem 96:179-194.

Huber KM, Kayser MS, Bear MF (2000) Role for rapid dendritic protein synthesis in hippocampal mGluR-dependent long-term depression. Science 288:1254-1257.

Huber KM, Roder JC, Bear MF (2001) Chemical induction of mGluR5- and protein synthesis-dependent long-term depression in hippocampal area CA1. J Neurophysiol 86:321-325.

Huber KM, Gallagher SM, Warren ST, Bear MF (2002) Altered synaptic plasticity in a mouse model of fragile X mental retardation. Proc Natl Acad Sci U S A 99:7746-7750.

Ireland DR, Abraham WC (2009) Mechanisms of group I mGluRdependent long-term depression of NMDA receptor-mediated transmission at Schaffer collateral-CA1 synapses. J Neurophysiol 101:1375-1385.

Irie F, Okuno M, Pasquale EB, Yamaguchi Y (2005) EphrinB-EphB signalling regulates clathrin-mediated endocytosis through tyrosine phosphorylation of synaptojanin 1. Nat Cell Biol 7:501-509.

Joly C, Gomeza J, Brabet I, Curry K, Bockaert J, Pin JP (1995) Molecular, functional, and pharmacological characterization of the metabotropic glutamate receptor type 5 splice variants: comparison with mGluR1. J Neurosci 15:3970-3981.

Kemp N, Bashir ZI (2001) Long-term depression: a cascade of induction and expression mechanisms. Prog Neurobiol 65:339-365.

Kullander K, Klein R (2002) Mechanisms and functions of Eph and ephrin signalling. Nat Rev Mol Cell Biol 3:386-475.

Li XM, Li CC, Yu SS, Chen JT, Sabapathy K, Ruan DY (2007) JNK1 contributes to metabotropic glutamate receptor-dependent long-term depression and short-term synaptic plasticity in the mice area hippocampal CA1. Eur J Neurosci 25:391-396.

Lin D, Gish GD, Songyang Z, Pawson T (1999) The carboxyl terminus of B class ephrins constitutes a PDZ domain binding motif. J Biol Chem 27:3726-3733.

Litschig S, Gasparini F, Rueegg D, Stoehr N, Flor PJ, Vranesic I, Prézeau L, Pin JP, Thomsen C, Kuhn R (1999) CPCCOEt, a noncompetitive metabotropic glutamate receptor 1 antagonist, inhibits receptor signaling without affecting glutamate binding. Mol Pharmacol 55:453-461.

Moult PR, Schnabel R, Kilpatrick IC, Bashir ZI, Collingridge GL (2002) Tyrosine dephosphorylation underlies DHPG-induced LTD. Neuropharmacology 43:175-180.

Moult PR, Gladding CM, Sanderson TM, Fitzjohn SM, Bashir ZI, Molnar E, Collingridge GL (2006) Tyrosine phosphatases regulate AMPA receptor trafficking during metabotropic glutamate receptor-mediated long-term depression. J Neurosci 26:2544-2554.

Mühlemann A, Diener C, Fischer C, Piussi J, Stucki A, Porter RH (2005) Constitutive activity modulation of human metabotropic glutamate $5 \mathrm{a}$ receptors in HEK293 cells: a role for key amino-terminal cysteine residues. Br J Pharmacol 144:1118-1125.

Naie K, Manahan-Vaughan D (2004) Regulation by metabotropic glutamate receptor 5 of LTP in the dentate gyrus of freely moving rats: relevance for learning and memory formation. Cereb Cortex 14:189-198.

Nakamoto M, Nalavadi V, Epstein MP, Narayanan U, Bassell GJ, Warren ST (2007) Fragile X mental retardation protein deficiency leads to excessive mGluR5-dependent internalization of AMPA receptors. Proc Natl Acad Sci U S A 104:15537-15542.

Neyman S, Manahan-Vaughan D (2008) Metabotropic glutamate receptor 1 (mGluR1) and 5 (mGluR5) regulate late phases of LTP and LTD in the hippocampal CA1 region in vitro. Eur J Neurosci 27:1345-1352.

Nicoletti F, Wroblewski JT, Novelli A, Alho H, Guidotti A, Costa E (1986) The activation of inositol phospholipid metabolism as a signaltransducing system for excitatory amino acids in primary cultures of cerebellar granule cells. J Neurosci 6:1905-1911.
Nosyreva ED, Huber KM (2006) Metabotropic receptor-dependent longterm depression persists in the absence of protein synthesis in the mouse model of fragile X syndrome. J Neurophysiol 95:3291-3295.

O’Riordan KJ, Huang IC, Pizzi M, Spano P, Boroni F, Egli R, Desai P, Fitch O, Malone L, Ahn HJ, Liou HC, Sweatt JD, Levenson JM (2006) Regulation of nuclear factor $\kappa \mathrm{B}$ in the hippocampus by group I metabotropic glutamate receptors. J Neurosci 26:4870-4879.

Overstreet LS, Pasternak JF, Colley PA, Slater NT, Trommer BL (1997) Metabotropic glutamate receptor mediated long-term depression in developing hippocampus. Neuropharmacology 36:831-844.

Pagano A, Ruegg D, Litschig S, Stoehr N, Stierlin C, Heinrich M, Floersheim P, Prezèau L, Carroll F, Pin JP, Cambria A, Vranesic I, Flor PJ, Gasparini F, Kuhn R (2000) The non-competitive antagonists 2-methyl-6(phenylethynyl)pyridine and 7-hydroxyiminocyclopropan[b]chromenla-carboxylic acid ethyl ester interact with overlapping binding pockets in the transmembrane region of group I metabotropic glutamate receptors. J Biol Chem 275:33750-33758.

Palmer MJ, Irving AJ, Seabrook GR, Jane DE, Collingridge GL (1997) The group I $m$ Glu receptor agonist DHPG induces a novel form of LTD in the CA1 region of the hippocampus. Neuropharmacology 36:1517-1532.

Park S, Park JM, Kim S, Kim JA, Shepherd JD, Smith-Hicks CL, Chowdhury S, Kaufmann W, Kuhl D, Ryazanov AG, Huganir RL, Linden DJ, Worley PF (2008) Elongation factor 2 and fragile X mental retardation protein control the dynamic translation of Arc/Arg3.1 essential for mGluR-LTD. Neuron 59:1-3.

Riedel G, Wetzel W, Reymann KG (1996) Comparing the role of metabotropic glutamate receptors in long-term potentiation and in learning and memory. Prog Neuropsychopharmacol Biol Psychiatry 20:761-789.

Rodenas-Ruano A, Perez-Pinzon MA, Green EJ, Henkemeyer M, Liebl DJ (2006) Distinct roles for ephrinB3 in the formation and function of hippocampal synapses. Dev Biol 292:34-45.

Ronesi JA, Huber KM (2008) Homer interactions are necessary for metabotropic glutamate receptor-induced long-term depression and translational activation. J Neurosci 28:543-547.

Rush AM, Wu J, Rowan MJ, Anwyl R (2002) Group I metabotropic glutamate receptor (mGluR)-dependent long-term depression mediated via p38 mitogen-activated protein kinase is inhibited by previous highfrequency stimulation and activation of $m$ GluRs and protein kinase $C$ in the rat dentate gyrus in vitro. J Neurosci 22:6121-6128.

Schnabel R, Kilpatrick IC, Collingridge GL (1999) An investigation into signal transduction mechanisms involved in DHPG-induced LTD in the CA1 region of the hippocampus. Neuropharmacology 3810:1585-1596.

Shigemoto R, Kinoshita A, Wada E, Nomura S, Ohishi H, Takada M, Flor PJ, Neki A, Abe T, Nakanishi S, Mizuno N (1997) Differential presynaptic localization of metabotropic glutamate receptor subtypes in the rat hippocampus. Neuroscience 17:7503-7522.

Takasu MA, Dalva MB, Zigmond RE, Greenberg ME (2002) Modulation of NMDA receptor-dependent calcium influx and gene expression through EphB receptors. Science 295:449-451.

Torres R, Firestein BL, Dong H, Staudinger J, Olson EN, Huganir RL, Bredt DS, Gale NW, Yancopoulos GD (1998) PDZ proteins bind, cluster, and synaptically colocalize with Eph receptors and their ephrin ligands. Neuron 21:1227-1229.

van Dam EJ, Kamal A, Artola A, de Graan PN, Gispen WH, Ramakers GM (2004) Group I metabotropic glutamate receptors regulate the frequency-response function of hippocampal CA1 synapses for the induction of LTP and LTD. Eur J Neurosci 19:112-118.

Volk LJ, Daly CA, Huber KM (2006) Differential roles for group $1 \mathrm{mGluR}$ subtypes in induction and expression of chemically induced hippocampal long-term depression. J Neurophysiol 95:2427-2438.

Wang L, Kitai ST, Xiang Z (2005) Modulation of excitatory synaptic transmission by endogenous glutamate acting on presynaptic group II mGluRs in rat substantia nigra compacta J Neurosci Res 82:778-787.

Wilkinson DG (2001) Multiple roles of EPH receptors and ephrins in neural development. Nat Rev Neurosci 2:155-164.

Yan QJ, Rammal M, Tranfaglia M, Bauchwitz RP (2005) Suppression of two major Fragile X Syndrome mouse model phenotypes by the mGluR5 antagonist MPEP. Neuropharmacology 49:1053-1066.

Zucker RS (1989) Short-term synaptic plasticity. Annu Rev Neurosci 12: $13-31$. 